\title{
Sex differences in risk factors for coronary heart disease: a study in a Brazilian population Vera S Castanho ${ }^{1}$, Letícia S Oliveira ${ }^{1}$, Hildete P Pinheiro ${ }^{2}$, Helena C F Oliveira ${ }^{3}$ and Eliana $\mathrm{C}$ de Faria*1
}

\author{
Address: ${ }^{1}$ Dept. of Clinical Pathology, School of Medicine; Center for Experimental Medicine and Surgery, University of Campinas São Paulo, \\ Brazil, ${ }^{2}$ Department of Statistics, Institute of Mathematics and Statistics, University of Campinas, São Paulo, Brazil and ${ }^{3}$ Department of \\ Physiology and Biophysics, Institute of Biology, University of Campinas, São Paulo, Brazil \\ E-mail: Vera S Castanho - vera@hotmail.com; Letícia S Oliveira - evillady@ hotmail.com; Hildete P Pinheiro - ildete@ime.unicamp.br; \\ Helena C F Oliveira - ho98@unicamp.br; Eliana C de Faria* - cotta@fcm.unicamp.br \\ ${ }^{*}$ Corresponding author
}

Published: 3 April 200I

BMC Public Health 200I, I:3
Received: 23 November 2000

Accepted: 3 April 200I

This article is available from: http://www.biomedcentral.com/I47I-2458/I/3

(c) 200 I Castanho et al, licensee BioMed Central Ltd.

\begin{abstract}
Background: In Brazil coronary heart disease (CHD) constitutes the most important cause of death in both sexes in all the regions of the country and interestingly, the difference between the sexes in the CHD mortality rates is one of the smallest in the world because of high rates among women. Since a question has been raised about whether or how the incidence of several CHD risk factors differs between the sexes in Brazil the prevalence of various risk factors for CHD such as high blood cholesterol, diabetes mellitus, hypertension, obesity, sedentary lifestyle and cigarette smoking was compared between the sexes in a Brazilian population; also the relationships between blood cholesterol and the other risk factors were evaluated.

Results: The population presented high frequencies of all the risk factors evaluated. High blood cholesterol (CHOL) and hypertension were more prevalent among women as compared to men. Hypertension, diabetes and smoking showed equal or higher prevalence in women in premenopausal ages as compared to men. Obesity and physical inactivity were equally prevalent in both sexes respectively in the postmenopausal age group and at all ages. CHOL was associated with BMI, sex, age, hypertension and physical inactivity.

Conclusions: In this population the high prevalence of the CHD risk factors indicated that there is an urgent need for its control; the higher or equal prevalences of several risk factors in women could in part explain the high rates of mortality from CHD in females as compared to males.
\end{abstract}

\section{Background}

Men and women share some coronary heart disease (CHD) risk factors such as age, dyslipidemia, hypertension, smoking, diabetes, obesity and physical inactivity. Besides that, women have additional risk factors, such as the use of contraceptives and the reduction of ovarian function with age [1].
There are important differences in the clinical manifestations of CHD between the sexes [1-7]. Besides that CHD was always considered a male problem, partly because of the 7-10 years time lag before its clinical appearance in women due to hormone differences and partly because of its higher incidence in men (although the difference decreases in postmenopausal women). After the 
sixties, with the entry of women into the labor market and exposure to stress, habitual smoking and fast food diets, their CHD mortality rates quickly increased. Recent studies have emphasized this increase and the fact that CHD is the leading cause of death among women [18]. Besides this, in the last 2 to 3 decades, the decrease in cardiovascular mortality rates as well as in the incidence of risk factors has been shown to be larger in men than in women [9].

In Brazil, the CHD mortality rate in women jumped from 10 to $25 \%$ from the sixties to the seventies [10-12] and now CHD constitutes the most important cause of death in both sexes and in all the regions of the country.

Interestingly, in Brazil the difference between the sexes in the CHD mortality rates is one of the smallest in the world because of high rates among women [13]. Since a question has been raised about whether or how the incidence of several CHD risk factors differs between the sexes in Brazil, we evaluated data on the occurrence of these risk factors in a population from the city of Campinas, State of São Paulo. We also measured the influence of the CHD risk factors on blood cholesterol.

\section{Materials and Methods}

The study comprised eight hundred and seventy-three individuals who volunteered to have their total blood cholesterol (CHOL) measured and to fill in a questionnaire with information on anthropometric data and on the presence of the following risk factors for the development of CHD: diabetes mellitus (DM), hypertension (HY), obesity (OBES), sedentary lifestyle (SEDEN) and cigarette smoking (SMOK). The data were collected in four different places of the city of Campinas, São Paulo, representing different social-economic populations - the City Government building, a branch of the Bank of Brazil, the State University of Campinas and a large Shopping Center - over a seven-day period, in november 1997. The volunteers were adults, from 20 to 82 years of age (y), 53\% males (M) and 47\% females (W), 6\% blacks and 94\% non-blacks mainly "Hispanics", similar frequencies described for the country and the state of São Paulo according to the 1998 census data. Their CHOL was measured in fingertip capillary blood by an enzymatic method (CHOD-PAP) through reflectance photometry utilizing the Reflotron (Roche Diagnostics, Indianapolis, IN, USA). Body mass indexes (BMI) were calculated from the informed height and weight $(\mathrm{kg}) /$ height $\left(\mathrm{m}^{2}\right)$ and used as a marker of excessive weight and obesity when equal to or above $25 \mathrm{~kg} / \mathrm{m}^{2}$.

The data were analyzed by the SAS statistical package utilizing the tests Student's "t", Chi-Square with or without Fleiss's method [14] and Fisher's exact, all at the sig- nificance level of $5 \%$. Comparisons were made between the sexes in the total population and at different age groups and between the age sub-groups in each sex. The cut off ages for CHD risk were established as: $\geq 45$ versus $<45 \mathrm{y}$ for men, and $\geq 55$ versus $<55 \mathrm{y}$ for women, according to the United States National Cholesterol Expert Panel" (NCEP) [15] recommendations followed by the "2 ${ }^{\circ}$ Consenso Brasileiro de Dislipidemias" (Brazilian Consensus on Dyslipidemia) [16].

A multiple logistic regression analysis was used to assess the influence of CHD risk factors on blood cholesterol concentration. The independent predictors of blood cholesterol were sex (men/women); age - all ages and the age group: $\geq 50$ versus $<50$ y; BMI $\geq 25$ versus $<25 \mathrm{~kg} /$ $\mathrm{m}^{2}$; race (blacks versus non-blacks) and the binary criteria (yes/no) of diabetes, hypertension, sedentary lifestyle and cigarette smoking. The dependable variable was defined as $\mathrm{CHOL}<5.18$-desirable levels, 5.18-6.19-borderline risk for CHD and $\geq 6.22 \mathrm{mmol} / \mathrm{L}$ - high risk for CHD, according to NCEP recommendations followed by the $" 2^{\circ}$ Consenso Brasileiro de Dislipidemias" (Brazilian Consensus on Dyslipidemia) $[15,16]$. In this case, since we have three levels of cholesterol, a proportional odds model was used in the logistic regression.

\section{Results}

In this population women had a trend toward higher ages than men did $(p=0.052)$, as seen in Table 1 . The BMI for the whole population is in the limit range for obesity grade I $\left(24.97 \pm 3.80 \mathrm{Kg} / \mathrm{m}^{2}\right)$. In men it was significantly higher than in women but the average difference between the sexes was only $3 \%$ (Table 1 ).

Table I: Blood cholesterol and anthropometric data among men and women and in the total population. Data presented as mean $\pm \mathrm{SD}$, interval, ( $\mathrm{n}=$ number of subjects)

\begin{tabular}{cccc}
\hline VARIABLE & MEN & WOMEN & TOTAL \\
& & & \\
CHOL & $4.92 \pm 1.09^{\mathrm{a}}$ & $5.10 \pm 1.22^{\mathrm{a}}$ & $5.00+1.22$ \\
$(\mathrm{mmol} / \mathrm{L})$ & $2.33-9.04$ & $2.67-9.14$ & $2.33-9.14$ \\
& $(459)$ & $(410)$ & $(869)$ \\
$\mathrm{AGE}$ & $46 \pm 15$ & $50 \pm 15$ & $47+15$ \\
$(\mathrm{y})$ & $20-82$ & $20-81$ & $20-82$ \\
& $(462)$ & $(41 \mathrm{I})$ & $(873)$ \\
$\mathrm{BMI}$ & $25.31+3.50^{\mathrm{b}}$ & $24.59 \pm 4.00^{\mathrm{b}}$ & $24.97+3.80$ \\
$\left(\mathrm{~kg} / \mathrm{m}^{2}\right)$ & $15.6-41.1$ & $16.7-38.9$ & $15.6-41.1$ \\
& $(454)$ & $(403)$ & $(857)$ \\
& & & \\
\hline
\end{tabular}

Student's " $t$ " test; axa: $p=0.033$, bxb: $p=0.005$

The population average CHOL (mean \pm SD) was $5.00 \pm$ $1.22 \mathrm{mmol} / \mathrm{L}$. Women showed statistically significant 
higher CHOL when compared to men, although the difference was small, around 3.5\% (Table 1). This sex difference was found in the CHD risk age groups: $5.75 \pm 1.14$ (age $\geq 55 \mathrm{y}$, women) versus $5.23 \pm 1.19 \mathrm{mmol} / \mathrm{L}$ (age $\geq 45$ $y$, men, "t" test, $p=0.001$ ). There was no difference in the younger age groups: $4.66 \pm 1.09$ (age 20-54 $\mathrm{y}$, women) versus $4.64 \pm 1.11 \mathrm{mmol} / \mathrm{L}$ (age $20-44 \mathrm{y}$, men, "t" test, $\mathrm{p}$ $=0.630$ ). Postmenopausal women presented higher CHOL levels when compared with younger women: 5.75 \pm 1.14 versus $4.66 \pm 1.09 \mathrm{mmol} / \mathrm{L}(\mathrm{p}=0.001)$ and in men CHOL also increased with age: $5.23 \pm 1.19$ versus $4.64 \pm$ $1.11 \mathrm{mmol} / \mathrm{L}(\mathrm{p}=0.001)$ as expected.

Table 2 shows that CHOL was higher than the recommended values for adults in $41 \%$ of the population. We found fewer women with CHOL in the reference range than men (54 versus 63\%). This statistically significant difference was due to the sub-population of women in the age group equal to and above $55 \mathrm{y}(\mathrm{p}=0.001$, Chisquare as expected $[4,7,17]$.

\begin{tabular}{|c|c|c|c|c|c|}
\hline GROUP & & $\begin{array}{c}\text { AGE } \\
\text { (years) }\end{array}$ & $\begin{array}{c}<5.18 \\
(\mathrm{mmol} / \mathrm{L})\end{array}$ & $\begin{array}{l}5.18-6.19 \\
(\mathrm{mmol} / \mathrm{L})\end{array}$ & $\begin{array}{c}\geq 6.22 \\
(\mathrm{mmol} / \mathrm{L})\end{array}$ \\
\hline \multirow[t]{3}{*}{ MEN } & $(462)$ & & $63(290)^{\mathrm{a}}$ & $23(106)$ & $14(66)$ \\
\hline & & $<45$ & 61 & 40 & 32 \\
\hline & & $\geq 45$ & $39^{b}$ & 60 & 68 \\
\hline \multirow[t]{3}{*}{ WOMEN } & $(4 I I)$ & & $54(222)^{\mathrm{a}}$ & $28(114)$ & $18(15)$ \\
\hline & & $<55$ & 80 & 45 & 31 \\
\hline & & $\geq 55$ & $20^{b}$ & 55 & 69 \\
\hline TOTAL & (873) & & $59(5 \mid 2)$ & $25(220)$ & $16(141)$ \\
\hline
\end{tabular}

()$=$ number of subjects; Chi-square and Fleiss tests : axa: $p=0.030$; bxb: $p=0.001$

Table 3: Prevalence (\%) of risk factors for coronary heart disease among men and women and in the total population

\begin{tabular}{clllll}
\hline GROUP & DM & HY & OBES & SEDEN & SMOK \\
\hline MEN & $3(460)$ & $19^{\mathrm{a}}(456)$ & $48^{\mathrm{b}}(462)$ & $46(46 \mathrm{I})$ & $24^{\mathrm{c}}(46 \mathrm{I})$ \\
WOMEN & $4(4 I I)$ & $27^{\mathrm{a}}(410)$ & $39^{\mathrm{b}}(4 I \mathrm{I})$ & $52(410)$ & $18^{\mathrm{c}}(410)$ \\
TOTAL & $4(87 \mathrm{I})$ & $23^{(866)}$ & $44(873)$ & $49(87 \mathrm{I})$ & $21(87 \mathrm{I})$ \\
\hline
\end{tabular}

()$=$ number of subjects; Chi-Square test; axa: $p=0.003$,bxb: $p=0.009$; cxc: $p=0.029$ DM-diabetes; HY- hypertension; OBES- obesity; SEDEN- physical inactivity; SMOK- smoking

As seen in Table 3, obesity (44\%) and sedentary lifestyle (48\%) were the most common risk factors in this population and diabetes the least common (4\%, as expected), but the data do not differ from those found in developed countries. Hypertension and smoking habit had practically the same frequencies around $20 \%$. Among men, in decreasing order of frequencies, the data showed: obesity, sedentary lifestyle, smoking, hypertension and diabetes. Among women, however, the decreasing sequence was different: sedentary lifestyle, obesity, hypertension, smoking and diabetes.

The comparison between the sexes showed that there were significant statistical differences in the frequencies of hypertension (1.4 times higher in women), obesity and smoking (respectively 1.2 and 1.3 times higher in men). Physical inactivity, the most frequent risk factor in this population, and diabetes were similar in the sexes.

Table 4 shows age distribution of risk factors in both sexes. Diabetes was not present in younger men. Its prevalence did not differ between the group ages in women. In the older groups, no differences were found between the sexes. Women presented higher frequencies of hypertension than men did in both age groups, indeed twice as high in the younger group (8X18\%). In both sexes the prevalence of hypertension was 2 to 3.5 times higher in the older ages as compared to the younger. The distribution of obesity between the age groups was not different in men, but in women the frequency was higher in older ages. In men the prevalence was higher than in women only in the younger group and no differences were found among the older groups. Physical inactivity was the only risk factor similar between the sexes in both age groups and equally frequent in the two age groups. The higher prevalence of smoking in men was found only in the older group. It was high in the younger groups and there were no differences between the sexes in those age groups (29 versus 26\%). Younger women smoked 4 times more than the older ones and younger men 1.6 times more.

Race, presence of diabetes and smoking habit did not have any significant effects in CHOL in this population as shown by the logistic univariate regression analysis. According to the multiple regression analysis, sex, age and BMI, the most significant effects to the model, did influence CHOL and were associated with hypertension and physical inactivity; because of the high association with BMI, they were not significant to the model in the presence of this variable. In the final model, age and sex presented a very significant interaction at all ages. Also BMI and sex interacted significantly at and after age $50 \mathrm{y}$. Table 5 presents the results of the logistic regression analysis with the selected test variables associated with CHOL-sex, age, BMI- and their respective logistic coefficients, $\mathrm{SE}$, p-value, odds ratios and confidence intervals in the total population. In Table 6 the same associations between variables for the cut off age of $50 \mathrm{y}$ are shown. 
Table 4: Prevalence (\%) of risk factors for coronary heart disease according to sex and age

\begin{tabular}{|c|c|c|c|c|c|c|}
\hline GROUP & $A G E(y)$ & DM & $\mathrm{HY}$ & OBES & SEDEN & SMOK \\
\hline \multirow[t]{4}{*}{ MEN } & $<45$ & $0^{a}$ & $8^{b}$ & $46^{c}$ & 42 & $29^{d}$ \\
\hline & & (239) & (238) & $(24 I)$ & $(240)$ & $(240)$ \\
\hline & $\geq 45$ & $7^{e}$ & $30^{f^{\prime}}$ & 51 & 50 & $18^{8}$ \\
\hline & & $(22 I)$ & $(218)$ & $(221)$ & $(221)$ & $(22 I)$ \\
\hline \multirow[t]{4}{*}{ WOMEN } & $<55$ & $3^{h}$ & $18^{i}$ & $33^{j}$ & 50 & $26^{k}$ \\
\hline & & $(251)$ & $(25 I)$ & $(25 \mathrm{I})$ & $(250)$ & $(250)$ \\
\hline & $\geq 55$ & $6^{\prime}$ & $4 \mathrm{I}^{\mathrm{m}}$ & $50^{n}$ & 56 & $6^{\circ}$ \\
\hline & & $(160)$ & (159) & $(160)$ & $(160)$ & $(160)$ \\
\hline
\end{tabular}

Statistical comparisons by the Fischer test; axe: $p=0.001$, axh: $p=0.007$; by the Chi-Square test; $\mathbf{b x f}, \mathbf{i x m}, \mathbf{j x n}, \mathbf{k x o}, \mathbf{g x o}: \mathrm{p}=0.00 \mathrm{I} ; \mathbf{d x g}: \mathrm{p}=$ 0.005; bxi, cxj: $p=0.020 ;$ fxm = 0.019 DM-diabetes; HY-hypertension; OBES-obesity; SEDEN-physical inactivity; SMOK-smoking

Table 5: Influence of coronary heart disease risk factors on blood cholesterol in the total population

\begin{tabular}{lccccc}
\hline VARIABLE & $\begin{array}{c}\text { LOGISTIC } \\
\text { COEFICIENT }\end{array}$ & SE & P-VALUE & ODDS RATIO ${ }^{\mathrm{a}}$ & 95\% Cl \\
\hline SEX & 1.655 & 0.534 & 0.002 & 5.232 & $1.839 ; 14.885$ \\
AGE ${ }^{\text {b,c }}$ & 0.075 & 0.008 & 0.009 & 1.078 & $1.061 ; 1.095$ \\
BMI & 0.208 & 0.141 & 0.141 & 1.231 & $0.933 ; 1.624$ \\
AGE ${ }^{*}$ SEX & -0.039 & 0.010 & 0.009 & 0.962 & $0.943 ; 0.981$ \\
\hline
\end{tabular}

$\mathbf{a}=$ odds ratio $=\mathrm{e}^{\text {sum of logistic coefficients } \mathrm{X} \text { age }} ; \mathrm{CHOL}$ above $6.22 \mathrm{mmol} / \mathrm{L} ; \mathbf{b}=$ all ages; $\mathbf{c}=<25$ and $\geq 25 \mathrm{~kg} / \mathrm{m}^{2} ; \mathbf{C l}=$ confidence interval

Table 6: Influence of coronary heart disease risk factors on blood cholesterol by age

\begin{tabular}{|c|c|c|c|c|c|}
\hline VARIABLES & $\begin{array}{c}\text { LOGISTIC } \\
\text { COEFFICIENT }\end{array}$ & SE & $\mathrm{p}$-VALUE & ODDS RATIO $^{a}$ & $95 \% \mathrm{Cl}$ \\
\hline SEX & 0.195 & 0.211 & 0.355 & 1.215 & $0.804 ; 1.836$ \\
\hline AGE $50^{b}$ & 2.074 & 0.243 & 0.009 & 7.961 & $4.946 ; 12.813$ \\
\hline $\mathrm{BMI}{ }^{\mathrm{c}}$ & 0.576 & 0.207 & 0.005 & 1.778 & I.185; 2.668 \\
\hline AGE $50^{*}$ SEX & -0.953 & 0.285 & 0.001 & 0.386 & $0.221 ; 0.674$ \\
\hline AGE $50^{*} \mathrm{BMI}$ & -0.551 & $0.28 I$ & 0.050 & 0.576 & $0.332 ; 1.000$ \\
\hline
\end{tabular}

$\mathbf{a}=$ odds ratio $=\mathrm{e}^{\text {sum of logistic coefficients }} ; \mathrm{CHOL}$ above $6.22 \mathrm{mmol} / \mathrm{L} ; \mathbf{b}=$ by age group $(<50$ and $\geq 50 \mathrm{y}) ; \mathbf{c}=<25$ and $\geq 25 \mathrm{~kg} / \mathrm{m}^{2} ; \mathbf{C l}=\mathrm{confidence}$ interval

Figure 1 summarizes the changes of prevalence of $\mathrm{CHOL}$ above $6.22 \mathrm{mmol} / \mathrm{L}$ according to sex, age (all ages up to $80 \mathrm{y})$ and BMI.

\section{Discussion}

The literature shows that there are differences between the sexes in the prevalence and impact of CHD risk fac- tors $[2,9,18]$. In the U.S.A. for example, some risk factors have high prevalence among women in the 20 to 74 year age group [19]: more than $1 / 3$ have hypertension, more than $1 / 4$ are hypercholesterolemic, more than $1 / 4$ present excessive weight and more than $1 / 4$ are sedentary. Furthermore, $51 \%$ of white women and $79 \%$ of black women above $45 \mathrm{y}$ have hypertension. The same is true 


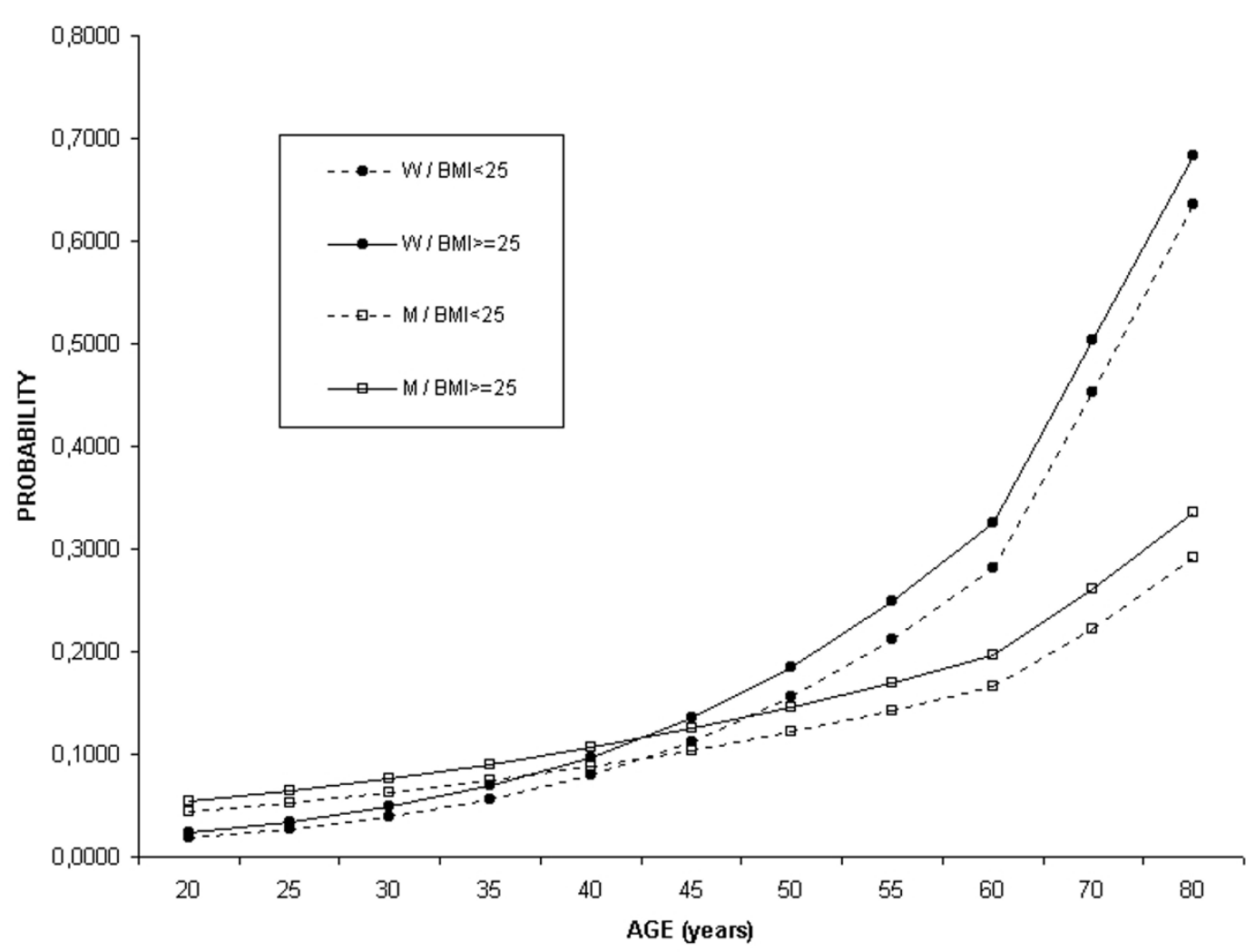

Figure 1: Probability of $\mathrm{Chol}>6.22 \mathrm{mmol} / \mathrm{L}$ by age, sex and $\mathrm{BMI}$

Figure I

Probability of $\mathrm{CHOL}>6.22 \mathrm{mmol} / \mathrm{dL}$ by age, sex and BMI.

for $71 \%$ of all women over $65 \mathrm{y}$ [3]. Hypertension is more frequent among women over $65 \mathrm{y}$ than among men at that age [20]. Diabetes has a prevalence of $7.7 \%$ [21].

In Brazil, the studies indicate the following prevalence [12]: hypercholesterolemia not determined [21], but more recently described in one study as $41 \%$ [22]; hypertension equal to 20-30\% [23], excessive weight and obesity, 53\% [21], physical inactivity, 74\% [21], diabetes, $7 \%$ [21] and smoking habit, 63\% [21].

The data presented here confirm the fact that the presence of CHD risk factors is a major health problem in women in Brazil (Table 3). Our findings of a lower prevalence of diabetes (4\%), excessive weight and obesity (44\%), physical inactivity (49\%) and smoking (21\%) in this study can be partially related to the fact that the information was self-reported although high CHOL and hypertension frequencies are the same as the ones described in the literature $[22,23]$.
It is important to emphasize that two of the major risk factors for CHD, high CHOL (Table 2) and hypertension (Table 3) were more prevalent among women as compared to men. High CHOL was present in the sub-population of women in the postmenopausal age, as expected, but pre-menopausal women in this population presented equal levels of CHOL when compared to men suggesting an additional risk at pre-menopausal ages.

Several studies demonstrate that the HDL-cholesterol level is a better predictor of mortality from CHD in women while the LDL-cholesterol level is a better predictive in men $[2,3]$. We did not fractionate lipoproteins in this study, but since hypercholesterolemia is one of the major well established risk factors for CHD in both sexes $[1,4]$, we can speculate that this could account for a possible higher risk for $\mathrm{CHD}$ in women in this population. Postmenopausal women tend to present a much higher chance of hypercholesterolemia due to elevated LDLcholesterol levels [17]. 
In Table 4 it is seen that the higher frequency of hypertension was present in both age groups. The higher frequency in postmenopausal women is in accord with the literature [24] but hypertension was also two times higher in younger women as compared to men from ages 20 to $44 \mathrm{y}$. Again, younger women in this population are more exposed to this major risk factor.

Hypertension is a well-established risk factor in both sexes. On the other hand, women have more complications from hypertension than men do. A more recent work has shown a strong association between CHD and hypertension in women [20].

The prevalence of diabetes was not different between the sexes (Table 3), but diabetes was not present in the younger group of men in this study, only in the women's group, indicating the presence of another very relevant risk factor in younger women. No differences were found between the sexes in the older groups (Table 4).

Diabetic women lose their "relative immunity" to CHD in relation to men: female diabetics are two times as likely to die from CHD than are male diabetics, so the same or a higher prevalence of diabetes among the sexes found in this study is quite unfavorable to women [7].

The prevalence of sedentary lifestyle was not different between men and women, but showed a small trend to higher frequencies in women (Table 4).

Physical inactivity increases CHD in both sexes [8]. Regular physical exercise favors women more than men, with respect to $\mathrm{CHD}$ [25].

Men presented a higher prevalence of obesity than women did only in the younger group, but there were no differences in the older age groups. The prevalence increased with age only in women aggregating another risk factor to the postmenopausal period.

Obesity was found to be an independent predictor of CHD in both men and women [26,27]. The distribution of fat is considered to be more important in both sexes than the overall degree of obesity, the centripetal distribution being a component of the atherogenic syndrome $\mathrm{X}[9,24,28]$.

Smoking, very prevalent in the younger groups, had higher incidence in men (Tables. 3,4 ). There were no differences between the sexes in the younger age groups leading to another undesirable risk at younger ages in women.
Tobacco use triples the risk of heart attacks among women, even during the pre-menopause period [3]; also, smoking women who are diabetic double their risk of death in relation to diabetic non-smokers [2]. Men are giving up tobacco at an increasing rate, which is not the case among women [21]. Also smokers have their first heart attack earlier than non-smokers: women 19 and men 7 years earlier [2].

The logistic analysis indicates that race, presence of diabetes and smoking habit did not contribute to CHOL in this population. It is probable that these risk factors do not operate through high CHOL. On the other hand, sex, age, BMI, as described earlier in other studies [4,29], hypertension and physical inactivity were the risk factors that influenced CHOL. Since sex and age are not modifiable, the control of obesity should be seriously implemented in Brazil.

Women had a higher risk than men of having CHOL $>6.22 \mathrm{mmol} / \mathrm{L}$ as their age increased (Table 5). These findings are in accord with the literature $[4,7]$ and in fact the population CHOL seemed similar to data obtained from an N.I.H. report [31]. From Table 5 it can be observed that the chance of having $\mathrm{CHOL} \geq 6.22 \mathrm{mmol} / \mathrm{L}$ was $23 \%$ higher in individuals presenting overweight and obesity. A more detailed analysis of these effects of sex, age and BMI on CHOL is seen in Figure 1. The prevalence of high CHOL was higher in post-menopausal women as compared to men, and it increased for both with age. The sex difference was present at all ages (up to $80 \mathrm{y})$, men having a higher prevalence in younger ages. After age $60 \mathrm{y}$, women presented a much higher frequency than men. The curves crossed around the age of $42.5 \mathrm{y}$ (close to the age of menopause, $47.5 \mathrm{y}$ as determined in the State of São Paulo [31]) for either overweight and obese individuals or not. The higher BMI is associated with a higher prevalence of CHOL.

Analyzing Table 6, in women at and above $50 \mathrm{y}$ the risk of having $\mathrm{CHOL}>6.22 \mathrm{mmol} / \mathrm{L}$ was 2 times higher than for men; before 50 y men had a $20 \%$ higher chance than women; at and above age $50 \mathrm{y}$ the chance of high $\mathrm{CHOL}$ for $\mathrm{BMI}<25$ is 1.02 as compared to $\mathrm{BMI} \geq 25$; below $50 \mathrm{y}$ the chance of high $\mathrm{CHOL}$ for $\mathrm{BMI} \geq 25$ is 1.8 higher than for BMI below 25, showing that factors related to obesity are much less influential in older ages, a period when the interaction age/sex predominated.

The results of this study demonstrate the need for the prevention of atherosclerosis by controlling the CHD risk factors in Brazil. This is shown by the high frequencies of a conglomerate of these risk factors such as high $\mathrm{CHOL}$, obesity, sedentary lifestyle, hypertension, diabetes and smoking in this population. Very important also is the 
fact that hypertension, diabetes and smoking were highly prevalent among younger women, the two first having higher frequencies than among men. These results could partially explain the small difference in the mortality rates from CHD between the sexes in Brazil [12].

\section{Acknowledgements}

We thank Merck Sharp \& Dohme, Brazil, for their technical support to carry out this study.

\section{References}

I. Bush TL, Fried LP, Connor-Barret E: Cholesterol, lipoproteins, and coronary heart disease in women, Clin Chem 1988, 34(8B): $\mathrm{B} 60-70$

2. Judelson DR: Coronary heart disease in women: risk factors and prevention. I Am Med Women Assoc. 1994, 49(6): I 86-197

3. Wenger NK: Hypertension and other cardiovascular risk factors in women. Am J. Hyperten 1995, 8:94S-99S

4. Castelli WP: Lipids, risk factors and ischaemic heart disease. Atherosclerosis 1996, 124 Suppl:SI-S9

5. Bass KM, Newschaffer JC, Klag MJ, Bush TL: Plasma lipoprotein levels as predictors of cardiovascular death in women. Arch Intern Med 1993, 1 53:2209-2216

6. Crook D, Seed M: Endocrine control of plasma lipoprotein metabolism: effects of gonadal steroids. In: Clinical Endocrinology and Metabolism. Edited by Betteridge DJ. USA: Bailliere's 1996, 85I-875

7. Kannel WB: Metabolic risk factors for coronary heart disease in women: perspective from the Framinghan study. Am Heart J 1987, II 4(2):413-419

8. Crook D, Stevenson JC: CHD in women - are serum lipids and lipoproteins important? In: Lipids: Current Perspectives . Edited by Betteridge \& Mosby . London: Mosby, 1996, 17I-186

9. Wingard DL: Sex differences and coronary heart disease. Circulation 1990, 81: 1710-1712

10. Mortalidade em Campinas - Informe trimestral do projeto de monitorização dos óbitos no município de Campinas, Secretaria Municipal de Saúde/ Prefeitura do Município de Campinas e Laboratório de Aplicação em Epidemiologia/DMPS/FCM/UNICAMP, São Paulo, Brasil. Boletim 1994, número I5:

II. Mortalidade geral pelos cinco principais grupos de causas (CID I0) segundo região de saúde (DIR) - Secretaria de Estado da Saúde. São Paulo. Boletim 1997,

12. Lotufo PA, Lolio CA: Tendência da mortalidade por doença isquêmica do coração no Estado de São Paulo:1970 a 1989. Arq Bras Cardiol 1993, 61:149-153

13. Lotufo PA: Epidemiologia das doenças isquêmicas do coração no Brasil. In: O Adulto Brasileiro e as Doenças da Modernidade Edited by Lessa I. São Paulo: Hucitec/Abrasco, 1998, I15-122

14. Fleiss JL: Statistical methods for rates and proportions. New York: John Wiley \& Sons Inc, 198I,

15. Expert panel on detection, evaluation, and treatment of high blood cholesterol in adults: summary of the second report of the National Cholesterol Education Program (NCEP) Expert Panel on detection, evaluation, and treatment of high blood cholesterol in adults (Adults Treatment Panel II). JAMA 1993, 269:3015-3023

16. $2^{\circ}$ Consenso Brasileiro sobre Dislipidemias: avaliação, deteç̧ão, tratamento. Arq Bras Cardiol 1996, 67:109-127

17. Colditz GA, Willett WC, Stampfer MH, Rosner B, Speizer FE, Hennekens $\mathrm{CH}$ : Menopause and the risk of coronary heart disease in women. $N$ Engl J Med 1987, 3 16( I 8): 1 105-1 I1 0

18. Brochier ML, Arwidson P: Coronary heart disease risk factors in women. Eur Heart J 1998, Suppl A:A45-52

19. Franco LJ: Epidemiologia do Diabetes Mellitus. In 0 Adulto brasileiro e as doenças da modernidade. Epidemiologia das doenças crônicas não-transmissiveis. Edited by Lessa I. São Paulo: Hucitec/Abrasco 1998, 123-137

20. Hsia Al: Cardiovascular disease in women. Med Clin North Am 1998, 82(I):1-19

21. Bloch KV: Fatores de Risco Cardiovasculares e para o Diabetes Mellitus. In O Adulto brasileiro e as doenças da modernidade. Epidemiologia das doenças crônicas não-transmissiveis. Edited by Lessa I. São Paulo: Hucitec/Abrasco 1998, 43-72
22. Guimarães AC, Lima A, Mota E, Lima JC, Martinez T, Conti AF, et al: The cholesterol level of a selected Brazilian salaried population: biological and socioeconomic influences. CVD Prevention 1998, I:306-317

23. Lessa I: Epidemiologia da Hipertensão Arterial. In O Adulto brasileiro e as doenças da modernidade. Epidemiologia das doenças crônicas não-transmissiveis. Edited by Lessa I. São Paulo: Hucitec/Abrasco; 1998, 7796

24. Fetters JK, Peterson ED, Shaw JL, Newby LJ, Durham NC: Sex-specific differences in coronary arthery disease risk factors, evaluation, and treatment: have they been adequately evaluated? Am Heart ] 1996, 131:796-813

25. Blair SN, Kohl HW III, Paffenbarger RS Jr, dark DG, Cooper KH, Gibbons LW: Physical fitness and all-cause mortality, a prospective study of healthy men and women. JAMA 1989, 262:23952401

26. Harris BT, Ballard-Barbach R, Makuc DM, Feldman JJ, Madans J: Overweight, weight loss, and risk of coronary heart disease in older women. Am J Epidemiol 1993, 137:1319-1327

27. Schenck-Gustafsson K.: Risk factors for cardiovascular disease in women: assessment and management. Eur Heart J 1996, 17:1-8

28. Freedman DS, Jacobsen SJ, Barboriak JJ, Sobocinski KA, Anderson AJ, Kissebah $\mathrm{AH}$, et al: Body fat distribution and male/female differences in lipids and lipoproteins. Circulation 1990, 8 I(5): 14981506

29. Willett WC, Manson JE, Stampfer MJ, Colditz GA, Rosner B, Speizer $\mathrm{FE}$, et al: Weight, weight change, and coronary heart disease in women, risk within the 'normal' weight range. JAMA 1995, 273(6):46|-465

30. Lipid Research Clinics Program Prevalence Study and Lipid Metabolism Branch, Heart, Lung and Blood Institute, National Institute of Health, publication No.80-I 527, In Tietz Textbook of Clinical Chemistry. Edited by Burtis C. and Ashwood E.: Phyladelphia: Saunders; 1999, 826-

31. Lima J Jr, Costa-Paiva L, Pedro AO, Pinto Neto AM: Effects of hormonal replacement therapy on blood pressure, body weight, and lipidic profile of post-menopause women. In: Schiff I, Utian WH, Graham DK, eds. Proceedings of the Ninth Annual Meeting of the North American Menopause Society. Baltimore: J North Am Menopause Soc. 1998, 268-269

\section{Pre-publication history}

The pre-publication history for this paper can be accessed here:

http://www.biomedcentral.com/content/backmatter/ 1471-2458-1-3-b1.pdf

Publish with BioMedcentral and every scientist can read your work free of charge

"BioMedcentral will be the most significant development for disseminating the results of biomedical research in our lifetime." Paul Nurse, Director-General, Imperial Cancer Research Fund

Publish with BMc and your research papers will be:

- available free of charge to the entire biomedical community

- peer reviewed and published immediately upon acceptance

- cited in PubMed and archived on PubMed Central

- yours - you keep the copyright

Submit your manuscript here: BioMedcentral.com http://www.biomedcentral.com/manuscript/ editorial@biomedcentral.com 